\title{
Communication
}

\section{THE TRUTH ABOUT STATE REGULATION OF UTILITIES IN WISCONSIN}

\author{
By G. C. Mathews, \\ Public Utilities Statistician, Railroad Commission of Wisconsin.
}

In the May number of The AnNals, Mr. Stiles P. Jones, secretary of the Voters League of Minneapolis, has made an attack upon methods and results of state regulation of public utilities in Wisconsin which puts state control in a very bad light. Because of the importance of the subject and the seriousness of the charges made by Mr. Jones, it appears that the facts with regard to the situation should be presented as fully as possible.

One significant fact with regard to the statements made by $\mathrm{Mr}$. Jones is that his information has been drawn, as he states, from the files of the Minnesota Home Rule League, an organization which came into existence to perform a single function, to defeat Governor Eberhart's plan for a state public utilities commission. The secretary of the league, who was actively in charge of its task of gathering information in opposition to Governor Eberhart's program had been campaign manager for the governor's opponent during the previous campaign. Whatever may have been the merits of the controversy in which the Home Rule League engaged with the governor's supporters, it seems that the circumstances under which the league did its work and the purpose for which it disseminated information were hardly such as would be likely to lead to a fair, impartial analysis of the situation in Wisconsin and to the presentation of the unbiased truth with regard to the activities of the Wisconsin commission. As Mr. Jones states, "The league first proceeded to comb Wisconsin," but there is evidence that the combing was not done to find the truth, but was done to find every situation which might conceivably be turned against the commission.

Unfortunately for those who have expected to find in Mr. Jones' paper an accurate résumé of Wisconsin conditions, many of the acts and opinions of the Wisconsin commission have undergone marvel- 
ous changes between the time when they were gathered in the comb of the league's investigator and the time of their appearance in the bulletin entitled "Regulation of Public Utilities in Wisconsin," of which Mr. Jones' article is merely a recapitulation.

Starting with eight general charges against commissions, the author proceeds to establish his case by citing what the league has apparently taken for facts. To reply to the charges made by $\mathrm{Mr}$. Jones it is necessary to take up his paper in detail and review the evidence upon which he relies for his conclusions. This will necessarily lead to a scattering rebuttal of his argument but because the weakness of his argument is due to the evidence which he uses and to his method of handling the various items of evidential data, a reply must be directed to the items of evidence upon which he rests his case.

A review of the evidence of which he makes use leads one to believe that the Home Rule League from whose files he draws his information has permitted itself to be misinformed in some particulars and that in others, its zealous pursuit of the truth has resulted in the drawing of erroneous conclusions and, incidentally, in the spreading abroad of a number of statements for which no foundation exists outside the somewhat prejudiced imagination of its sponsors.

But let us look at the proof by which the league's case is supported.

In his article, Mr. Jones quotes the Home Rule League to the effect that out of 134 cases decided by the commission up to March, 1912, "Public service corporations of Wisconsin asked the commission for increase of rates in 52 cases. Substantial increases were granted in 43 cases and small increases in 7 additional cases. In other words, some increase was granted in nearly every case where it was asked, some were granted when not asked for." The statement is made that 38 of the 134 cases were telephone cases.

Up to March, 1912, the commission actually issued 126 decisions in utility cases, although the number of actions disposed of was substantially as stated by the league.

A count of the decisions shows, however, that 51 of the decisions instead of 38 as stated by Mr. Jones were issued in telephone cases. Probably this is a mere oversight, but it is significant, because a large part of the increases authorized by the commission came in telephone cases.

Of the 51 telephone decisions, 32 were issued in cases where utilities asked for authority to increase rates. Of these, 22 were granted; 
5 were granted in part, and 5 were refused, although the league states that the commission has granted increases in all but two cases where utilities asked for them. Of the 27 cases in which telephone utilities were permitted to increase rates, 24 resulted in actual increases of revenue. In the other 3 cases decreases in some classes of rates more than offset the increases authorized. Of the 24 increases authorized, 8 were increases of $\$ 200$ per year or less, and only 6 were over $\$ 1,000$. In most of the cases the increase can be computed mathematically and in the others it can be estimated very closely. The total increases permitted in the case of telephone utilities were $\$ 17,530$ per year, equal to $34 / 100$ of 1 per cent of the telephone revenues of the state for the year ending June 30, 1912. Included among these increases were such as the increase in the case of the Ettrick Telephone Company which was authorized to increase its rate from $\$ 3.00$ to $\$ 4.00$ per year, and those in the cases of the Morris Telephone Company, which was authorized to charge 50 cents per month, of the PewaukeeSussex Telephone Company, where an increased rate was authorized in cases where rentals were not paid promptly, and Platteville, Rewey, and Ellenboro Telephone Company where an increase was authorized, to be effective when full metallic service was installed. Another fact which should be noted in connection with the increases which the commission has permitted is that of the 24 telephone utilities whose revenues were increased by authority of the commission, 9 were mutual companies having a total of 4049 subscribers, of whom 2454 were stockholders. In these cases, therefore, the applications to increase rates came from the very parties who would pay the greater part of the increase.

In the cases where increases were authorized the increases were granted because the companies were not earning enough to provide adequate service and meet the depreciation on the equipment, to say nothing of providing a return on capital invested.

Among the smaller telephone companies a general practice has prevailed of extending the plant out of such earnings as would properly have been used to provide for depreciation, without adding to the value of the plant as shown on the utility's books. Among the mutual companies, stockholders frequently did construction work without charge to the company. As a result, the value as carried on the books of these companies, has been less than the actual investment. Basing our figures upon this conservative statement of value, we find that all the telephone companies for which the commission 
authorized increases earned 2.6 per cent upon the value of their property in 1912, after the increases became effective, and 4.1 per cent in 1913. In this case computation depreciation was computed at 7 per cent, although in some cases a higher allowance should be made which would still further decrease the amount available for return upon investment. Mr. Jones does not state that a public utility should not be entitled to a reasonable return upon its investment, but if the commission is to be criticised for permitting telephone companies to increase rates, the conclusion must be that the critics do not believe that a utility is entitled to earn a reasonable rate of interest.

The Home Rule League is quoted further by Mr. Jones as follows: "In a term of five years, during which the trend of public service charges was so strongly downward, the trend under the Wisconsin commission was uniformly upward." What the facts are with regard to water, gas, and electric rates in Wisconsin we shall see later, but there is one point in the statement quoted which should be noted here. The trend of public utility charges in the telephone business has not been strongly downward. Most of the small, independent telephone companies in the country were started with a very few subscribers, by parties who know but little about the cost of conducting a telephone business. As the business expanded the necessity for continuous service, for metallic lines and for improved standards of maintenance has increased the cost of conducting the business. To this must be added the tardily recognized necessity of providing for depreciation of property, and the fact that wages of operators and of repairmen have gone steadily upward, without corresponding savings in efficiency, such as have made reduced prices possible in other public utilities.

The cost of conducting the telephone business has not been decreasing.

In spite of all this, the increases in telephone rates authorized by the commission have been extremely small. In 1912, 647 telephone exchange systems and 26 toll systems reported to the commission. In almost five years from 1907 to March, 1912, the commission authorized increases of revenue for 24 telephone utilities, 9 of which were mutual companies. In other words, about one telephone company out of 27 was permitted to increase its rates during five years; the total increase amounted to about one-third of 1 per cent 
of the telephone revenues in the state, and after the increases were authorized the companies were earning a smaller return on their investment than could have been obtained from first-class farm mortgages.

Nineteen cases were handled by the commission during the time alluded to by Mr. Jones, in which complaints of various kinds against telephone utilities were concerned, or in which the applications did not relate to rates. In six of these cases service matters were involved, and in five cases improvements were ordered. Two cases related to pole removal, and in one of these the removal was ordered. Rates were involved, either directly or indirectly, in ten cases. In four of these cases rates were reduced; in five cases the proceedings were dismissed, one of them because the complainant could not lawfully file a complaint, and in one case rates were increased in order to provide enough revenue to enable the utility to furnish adequate service. Discriminations were ordered discontinued in two cases.

In leaving this matter of telephone rates, we should remember that telephone companies in Wisconsin never possessed municipal franchises, and that prior to the enactment of the public utility law rates of telephone utilities were not fixed by any public authority. Without commission regulation telephone utilities would have been free to charge what rates they chose and every increase upon which the commission passed could have been made without being passed upon by any governmental body.

From what has been said, it will probably be clear that what the Home Rule League and Mr. Jones have charged against the Wisconsin commission does not have a firm foundation of facts, as far as the telephone utilities are concerned.

A study of the other cases shows facts almost equally at variance with the charges made by the league.

Only one heating utility case was handled during the period chosen by the league for its study. This was an investigation, on the commission's motion, of heating rates in Milwaukee, and the facts obtained showed that no order could be issued.

There was one case against a toll bridge utility and as a result of its investigation the commission ordered extensive improvements to be made.

Four cases involved gas rates. The Manitowoc Gas Company was authorized to reduce its illuminating gas rate and put in a 
25-cent service charge, which service charge was eliminated within a short time. The net reduction amounted to from $\$ 6,000$ to $\$ 8,000$ per year.

The Green Bay Gas and Electric Company was authorized to put in an optional gas rate and a minimum monthly bill of 40 cents. The optional rate was optional with the consumer so that it could not amount to an increase in any case.

The rates of the Racine Gas Light Company were reduced about $\$ 13,000$ per year and a reduction of the gas rates of the Wisconsin Traction, Light, Heat, and Power Company was made by which an annual reduction of about $\$ 12,000$ was effected in Appleton, Neenah, and Menasha.

The water cases handled by the commission during the period studied by the league number nineteen. Increases in rates were permitted in only two cases, and one of these was a municipally-owned plant which had been losing so much money that the tax-payers entered complaint and asked that the plant be made self-supporting. In the other case the utility still earns less than 6 per cent, with a very economical management.

Two applications were made by water utilities for authority to increase rates, but both were dismissed. In six cases lower rates were asked for but the earnings of the utilities did not justify a reduction, but in one of these cases improvements in service were ordered. In four cases new rate schedules were ordered. In one of these cases the total revenue was practically unchanged, and in the other three, reductions were made. Six of the other cases related to service and in every case improvements were ordered. In one case a rule fixing terms for payment for service was approved with the consent of both parties to the case.

Of electric utility cases the commission handled 42 during the time in question, i.e., it handled 42 cases in which matters relating to the electric business were the only ones involved. Twenty-three of these cases involved applications by the utilities for authority to increase or adjust rates. In 20 cases the applications were granted, and in 3 cases they were denied, but this does not mean that the revenues of the utilities were increased in 20 cases.

In the Marinette case revenues were decreased as a result of the granting of the utility's application; in 10 cases there was no increase of revenues, but merely an adjustment of rates by which discrimina- 
tory or inequitable practices were eliminated, and in 9 cases revenues were increased. Yet the Home Rule League, as quoted by Mr. Jones, states that substantial increases were authorized by the commission in 43 cases out of 52 applications, and small increases in all but 2 of the others.

The 9 electric utilities which were permitted to increase their rates earned for interest in 1912, 6.4 per cent upon the value of their property, using the more conservative appraisal value, instead of the book value, which for the electric utilities often exceeds the actual value. For 1913, the amount earned for interest was equal to 7.2 per cent of the value of the property. The electric business has grown very rapidly during the past few years and yet theincreases authorized by the commission did not yield a 7 per cent return until 1913.

Nineteen electric utility cases involved other matters than applications by utilities to change rates. Service was involved in 7 of these, and improvement was ordered in 5 cases. In one other case the company made the improvement without an order. Five cases were dismissed for lack of jurisdiction. Three cases arose from complaints against utility rates and the complainants were upheld in two cases, and in one case a new schedule was recommended but no order was made. In one of the other cases the commission acted as a board of arbitration; in two cases investigations of discriminatory practices were made on motion of the commission; in one other case discriminatory rates were discontinued and in the other a proposed rule of the utility was rejected.

Eight decisions of the commission were issued in joint utility cases, i.e., cases which involved electric and water rates, or electric and gas rates, etc. In one of these, standards of gas and electric service were established. General reductions were made in rates in five cases. A new schedule was provided upon the application of the Jefferson municipal light and water plant, and an increase was authorized in only one case and then only as applied to business lighting. This was in La Crosse.

This somewhat lengthy and probably tedious summary of the decisions has appeared to be justified because the statements regarding rate cases made by the Home Rule League and quoted by $\mathrm{Mr}$. Jones are not true in a single important particular. The league says that there have been substantial increases in 43 cases and substantial 
decreases in only 3 cases. Aside from the fact that the numbers have not been correctly stated by the league, the word "substantial" has undergone a remarkable change of meaning in its use. Even taking every increase which the commission has authorized the number is less than the 43 listed as "substantial." But the league's definition of the word "substantial," as applied to the decreases, is very far from what it is as applied to the increases. The decrease in the second Madison Gas and Electric case alone, which, by the way, was taken up on motion of the commission, was more than $\$ 8,000$ greater than the increases authorized in all the telephone cases taken together.

Summarized, the facts are that increases in revenues were permitted in 37 cases instead of in 50, and all but 13 of these were cases of small telephone companies. Revenues were decreased in 17 cases up to March, 1912, aggregating annually between $\$ 132,000$ and $\$ 135,000$, and being more than $\$ 100,000$ greater than the sum of all increases. Increases were refused outright in 10 cases, instead of in 2 , as stated by the league, and in 15 cases new schedules were authorized which removed discriminations but did not increase revenues. Surely the league would hardly wish to criticise the commission for removing discriminations even though it were done on application of the utility, as long as no increase in revenues resulted, yet this is the conclusion to be drawn from its statements.

A count of the cases shows that the service was involved directly in 23 cases and indirectly in one or two more, instead of in 34 cases, as stated by the league. The league has, however, hit upon the truth in its statement that improvements were ordered in 20 cases, which is the only correct statement in the extract quoted by $\mathrm{Mr}$. Jones.

The criticism of Mr. Jones' paper does not end with what he states on the authority of the Home Rule League. Many of the statements for which he assumes the responsibility are not true and others are so illogical that it is surprising that the author could have made himself believe in his own conclusions. To refute his arguments requires merely a statement of the truth. For example, he states that, "Many of the estimated reductions made during the past year are held up awaiting the action of the court of last resort, with the people paying the old rate in the interim." As a matter of fact there are only two reductions so held up, and they are the Milwaukee and the Superior street railway cases which he mentions. 
Mr. Jones does not explain by what mental process he construes the fact that these two utilities have appealed to the courts as an argument against the commission. It might be pertinent to inquire with what mysterious power Mr. Jones would clothe the cities so that with home rule in utility regulation, the utilities would no longer exercise their rights of appeal. The commission is criticised for not reducing rates and then it is further criticized because utilities take every legal means of protecting their earnings.

Another statement made by Mr. Jones which is not a statement of the truth is that the commission has refused to permit the sale of hydro-electric power in Madison. The falsity of this statement was pointed out to the secretary of the Home Rule League at the first annual meeting of the League of Minnesota Municipalities in October, 1913, but as evidence of their earnestness in getting at the truth of the situation in Wisconsin, they have repeated their misleading statements in their recent bulletin and here we find the same charges. The truth is that the city of Madison, the Prairie du Sac Company, or any other person or organization has never asked the commission to permit the sale of hydro-electric power in Madison. No case has ever come before the commission on this matter. The power plant is not yet completed. The commission would indeed be ridiculous if it had attempted to pass upon a situation which never was brought before it. But "the citizens of Madison have stripped for battle" says Mr. Jones, thereby giving the impression that the commission is fighting with the people of Madison. The truth is that the Madison Board of Commerce has hired an expert to investigate the question of securing hydro-electric power and to secure the facts which will determine whether any action shall be brought before the commission. The Madison story as told by the Home Rule League and reiterated by Mr. Jones is a political fabrication, pure and simple, and the league officials knew the facts when the story was published.

We are told by Mr. Jones that the utilities are in politics in Wisconsin, but that in Duluth such is not the case. It is significant that in all comparisons, with a single exception in the case of street railway service, which Mr. Jones and the league have made between conditions in Minnesota and in Wisconsin, Duluth has been the only example cited in Minnesota. It is stated that in Superior the public service companies "come pretty near to dominating the politics of 
that city," but the author does not explain how he reconciles this statement with his other statement that the people of Superior voted seven to one to ask the legislature for authority to take over the street railway. A vote of seven to one for municipal ownership is not very strong testimony that the community is politically in the grip of the corporation.

Comparison is also made of the price of gas in Duluth and Superior. Duluth has a population about twice as great as that of Superior. In 1912 the Duluth plant sold 325,000,000 cubic feet of gas to about 8,000 consumers. The Superior plant sold a little over $67,000,000$ cubic feet to 3,400 consumers. Sales in Duluth were about twice as great per consumer as in Superior, and fixed charges of the plant were distributed over a vastly greater volume of sales. The comparison between Duluth and Superior is certainly not as fair as a comparison between St. Paul and Minneapolis, but the home rule partisans have refrained from calling attention to the difference in rates between those two cities. If the author had cared to make a fair comparison he would have compared Minnesota cities with cities of similar size in Wisconsin. For example, Winona, Minn., might have been compared with Eau Claire; St. Cloud and Stillwater, Minn., with Ashland, and Manitowoc; Red Wing and Faribault, Minn., with Watertown and Waukesha; or Moorhead and South St. Paul, with Stoughton and Monroe, in nearly all of which cases the Wisconsin rates would have been found lower than those in Minnesota.

Furthermore, the Duluth gas plant is municipally owned and whatever advantages it might seem to have in any fair comparison would be found to be due in large measure to the fact that many actual expenses, such as cost of supervision, depreciation, and taxes which the city has foregone, have not been fully met from the earnings of the plant, but have been borne by the tax-payers.

With regard to municipal ownership the author charges that except in water works cases, the attitude of the commission "has been distinctly obstructive at all times, on the theory that municipalities are not competent to perform such duties of city administration." There is not even a semblance of truth in this statement. The commission has no discretionary power, of any kind whatever, which would enable it to obstruct municipal acquisition. The statutes of Wisconsin state very clearly how and by what means cities may secure municipal ownership. Electric plants have been municipalized in 
Brodhead, Kaukauna, Cashton, and Manitowoc. The Grand Rapids and Prairie du Sac cases are pending at this writing. In every case where a city has taken the proper steps to purchase the property of a utility the commission has valued the property, as required by law. No other result would have been possible and at no time has there been any attitude "obstructive" to the securing of municipal ownership.

Mr. Jones criticises the indeterminate permit feature of the law and makes four charges which are entirely unsupported by the facts. To answer these charges it will perhaps be best to take them up in order. Speaking of the indeterminate permit, Mr. Jones states that: (1) "It has prolonged the life of privately owned utilities through its obstructive effect on municipal ownership." Whether the indeterminate permit has had an obstructive effect on municipal ownership must be judged from the facts of the case. According to the Wisconsin law as it was prior to the adoption of the indeterminate permit feature a city could take over a private plant only in case it could prove the necessity of such acquisition in court. The expressed wish of the voters of the city was of no value unless the city could prove that municipal ownership was necessary. As the indeterminate permit law was passed in 1907 the acceptance of the indeterminate permit was made optional with the utilities, but the acceptance of an indeterminate permit by a utility bound the utility to agree that its property could be purchased by the city at any time, without the necessity for municipalization being proved. That is, the utilities waived all rights of court review as to the necessity of purchase. This was the situation up to 1911 . At that time a large number of the utilities had accepted the indeterminate permits and thereby agreed to sell their plants to the cities whenever the voters should determine to purchase them. The following statement shows the facts as taken from the 1911 reports, as to the extent to which the utilities had consented to sell their plants without the necessity of

\begin{tabular}{|c|c|c|c|c|c|c|}
\hline Utility & $\begin{array}{l}\text { Prop. \& plant } \\
\text { of co's.rec'g. } \\
\text { indeterminate } \\
\text { permits }\end{array}$ & $\begin{array}{l}\text { Total private } \\
\text { property } \\
\text { and plant }\end{array}$ & $\underset{\text { cent }}{\text { Per }}$ & $\begin{array}{l}\text { Total oper. } \\
\text { revenue of co's. } \\
\text { rec'g. indeter- } \\
\text { minate permits }\end{array}$ & $\begin{array}{c}\text { Total private } \\
\text { operating } \\
\text { revenue }\end{array}$ & $\begin{array}{l}\text { Per } \\
\text { cent }\end{array}$ \\
\hline $\begin{array}{l}\text { Electricity... } \\
\text { Gas.......... } \\
\text { Water....... } \\
\text { Heat........ }\end{array}$ & $\begin{array}{r}\$ 10,822,218.61 \\
\mathbf{5}, 497,247.22 \\
9,652,200.59 \\
921,550.26\end{array}$ & $\begin{array}{r}\$ 38,166,778.44 \\
25,063,185.93 \\
10,361,337.47 \\
1,278,419.71\end{array}$ & $\begin{array}{l}28.4 \\
21.9 \\
93.2 \\
17.2\end{array}$ & $\begin{array}{r}\$ 2,027,263.65 \\
880,37.65 \\
907,006.37 \\
150,542.48\end{array}$ & $\begin{array}{r}\$ 5,238,614.41 \\
4,159,159.44 \\
982,392.63 \\
231,944.56\end{array}$ & $\begin{array}{l}38.7 \\
20.7 \\
92.3 \\
64.8\end{array}$ \\
\hline
\end{tabular}


court review. This includes all of the privately-owned water, gas, electric and heating utilities. Telephone utilities are not included because they had never held municipal franchises.

Out of 140 private electric utilities, 53 voluntarily took the indeterminate permit, 15 out of 40 gas utilities, 19 out of 31 water utilities and 7 out of 14 heating utilities. Of a total of 225 private utilities, the necessity of proving in court that municipal ownership was necessary was eliminated in 94 utilities. All private utilities which have started operations since 1907 have been obliged by law to acquiesce in the right of the municipality to purchase the plant at any time. In 1911 the legislature extended the indeterminate permit feature to all utilities, and those who accepted the permit under compulsion probably still have the right to have the necessity of purchase proved in court. That the permit has not had an obstructive effect on municipal ownership is further evidenced by the fact that the water plants in Sheboygan, Fond du Lac, Appleton, Lake Geneva, Manitowoc, Whitewater, Oshkosh, and Antigo, have been purchased by the cities and that water plant purchase cases are pending for Racine, Janesville, and Beaver Dam. There are only 25 privately-owned water plants in Wisconsin at the present time. Foui electric plants have been municipalized and two cases are now pending.

The second charge which Mr. Jones makes is that the indeterminate permit "has entrenched the companies in their monopoly grip upon the cities, with the result of continued excessive charges and inefficient service." It is true that the permit gives utilities a monopoly of the field they serve. If the statement that rates are excessive and service inadequate, where utilities are protected by the permits, were true, the utilities might be said to have a "monopoly grip." The number and nature of the commission's orders to improve service and the inspection carried on by its engineering department have resulted in improvements in service until there is no question but that service furnished by the utilities of Wisconsin is superior to that of surrounding states. The charge that rates are excessive and service inadequate is one for which Mr. Jones has failed to cite any evidence whatever. If rates are excessive and if home rule is the proper means of regulation, how would we account for the fact that in two of the three reductions which have been made in electric rates in Madison, the commission opened the cases on its own motion, because neither the city not its citizens would file a 
complaint? The advantages and savings which result, in the long run, from having a city supplied by a single utility are too well known to readers of The AnNals to need repetition in this discussion.

The third criticism of the indeterminate permit is that "It has made it impossible for municipalities to secure cheaper or better street light service through the construction of municipal plants." So far as any record which has ever been introduced before the commission shows no municipality could get cheaper and better street lights by constructing its street lighting plant. The city of Milwaukee is investigating the question at present but no conclusions have been reached by its experts.

The final charge against the permit is that "It has nullified existing contract obligations between cities and utility companies, often to the great advantage of the companies."

No contract could possibly be nullified by the permits. That much of the statement needs no explanation. Non-contractual features of franchises have been altered but cities have often been the parties to take advantage of this. The law provides that rates shall be reasonable and service adequate, and these have been regulated by the commission so far as they were not matters of contract. To state that contractual relationships have been changed is to ignore the fact that the supreme court of Wisconsin has upheld a contract between a city and a public utility under whose terms the city was really receiving free service (141 Wis. 363, Superior $v$. Douglas County Tel. Co.).

Mr. Jones attacks the commission severely for its valuation methods. It should, however, be remembered that the elements which must be considered in valuing utility property have been determined by the courts and that the Wisconsin commission has no choice as to the inclusion of the various elements. If the commission were not to give consideration to such elements as going value, its decisions would be reversed in court. Neither the commission nor any municipality could enforce an order which would not yield a reasonable return upon a valuation of the property, including all valuation elements which the courts have held must be considered. Mr. Jones' real contention should not be with the commission for including elements which, under the law, it had no power to exclude, but should be rather with the courts, by whom the legal principles have been laid down. 
Aside from the unreasonableness of his attack upon the commission for including in its valuations elements which must, legally, be included, there is another objection to the statements that Mr. Jones has made with regard to the commission's method of valuation, which is, that the facts are not correctly stated. Speaking of going value, he says: "In effect, it (the commission) capitalizes the company's early losses, puts upon the public all the hazards of the business, and assures the utility of liberal returns on its investment from the very beginning of operation." Nothing could well be further from the truth. The commission has never included losses which did not represent a reasonable outlay in developing the business. The risk due to abnormal conditions, to lack of necessity for the utility in the community served, to poor business management, has been placed upon the utility. All that has been included as an element of value is the cost of building up the business under normal conditions. The position of the commission is stated in its decision in State Journal Printing Co. v. Madison Gas and Electric Co. (4 W.R.C.R. 501-586) as follows: "As already stated, when such deficits are due to abnormal conditions, or when due to bad management, defective judgment, extravagance, lack of ordinary care and foresight, unduly high capital charges, and other causes of this nature, it is manifestly clear that they should be accorded little or no consideration in either the valuation or the rates." Apparently Mr. Jones has not known what the commission's attitude has been on this question. At least he has failed to state correctly the facts in the case.

A number of other points in the commission's valuations are criticised, among them the inclusion of property donated. The valuations of railroad property placed before the United States supreme court in the Minnesota rate case, included all land, regardless of its method of acquisition. The fact that the commission has been upheld in its valuations by the Wisconsin supreme court shows that the commission's valuations have been made in accordance with the law, and we are not told by Mr. Jones how any other valuation could be upheld, even with home rule in utility affairs.

In speaking of the inclusion of service connections, the author includes only enough of the opinion of the commission to give the impression which he wished to convey, i.e., that the commission has included service connections, paid for by consumers, in its valuation. He fails to quote a complete sentence, of which the missing portion 
reads as follows, "from the point of view of equity full consideration may well be given to the fact that a large number of services have been paid for by consumers, and that certain lands have been donated to the company by the municipality," City of Ashland $v$. Ashland Water Company (4 W.R.C.R. 273, 306).

The Appleton and Oshkosh cases are quoted as showing that the commission includes in its valuations in municipal purchase cases the cost of paving over mains which has not been disturbed by the utility. An examination of the facts in these cases, however, shows that the final value fixed by the commission included only the present value of the property, exclusive of pavements, plus a small allowance for going value. The cost of undisturbed paving is not in the final valuation, although it is shown as one element in the cost of reproduction which is quite a different thing from the price for municipal acquisition. In the Ashland case previously cited and on the page following that from which Mr. Jones quotes with reference to services, the attitude of the commission with regard to paving over mains is expressed as follows:

While this item (paving over mains) is unquestionably a valid one in estimating the cost of reproduction new, it is not an item which, on its face, must be included in the value of the property for rate-making purposes. The fact is, that respondent company was obliged to cut through no pavements whatsoever in the original construction of its system. If the company had not since been compelled to cut through paving, nothing whatever should be allowed under that head in this proceeding. (Ashland $v$. Ashland Water Company, 4 W.R.C.R. 273-307.)

This seems to state clearly the commission's position with regard to paving, which is quite different from the position described by the author.

Mr. Jones scores the commission for its order in the Milwaukee Street Railway case, in which the fare was fixed at 13 tickets for 50 cents, which case is now pending in the United States courts. He says, "Compare such a meager and uncertain result with what Cleveland, Columbus, Toledo, and Detroit with 3-cent fares have secured for themselves through the direct action of their city councils." This statement requires some attention to be given to the conditions in the cities mentioned. The most recent data available regarding Columbus are contained in the 1914 McGraw Electric Railway Manual. This publication shows passenger revenues per revenue passenger for 1912, of 3.32 cents. The 1913 figures are not given. 
The following quotation from the May, 1914, issue of Public Service, bears upon the Toledo situation:

The company, through its attorneys, had notified the city council that it would not recognize the Schreiber ordinance as valid nor accept three cents as fare, and shortly before midnight on March 27 , all its conductors were instructed that they must not accept a 3-cent fare, except in the 3-cent fare hoursbetween $5: 30$ and $7: 30$ in the morning and $4: 30$ and $6: 30$ in the evening-but that no passenger must be ejected from a car for refusing to pay the regular fare. Because of this order there was very little confusion even on the first night, when those who were out were expecting some sort of excitement and more or less disposed to start something of the kind. In the next few days some persons rode free after tendering three cents, and refusing to pay any more, and on the first Sunday there was more or less family joy-riding at the expense of the company, but in less than a week the novelty of these conditions had worn off and nearly all the passengers paid their fares as before. Now nearly eighty-five per cent of those who ride are paying full fare, and the company reports that many of the others are not regular passengers and would not be using the cars at all if it were not for the chance to ride free.

The Detroit situation is explained by Henry M. Hyde in a recent issue of the Chicago Tribune. As explained by Mr. Hyde there is a 3 -cent fare on the so-called Pingree lines covering only about 60 miles of streets. On the other lines the ticket fare is 7 for 25 cents, except that during the rush hours 8 tickets for 25 cents are sold, with no transfer privilege.

The following extract from a letter by Peter Witt, city street railroad commissioner of Cleveland, states the rates in Cleveland.

The rate still is what it has been during the past three years, 3 cents with a penny charge for transfer and a penny rebate. It is quite possible that owing to the scrapping of a lot of obsolete machinery the penny charge for a transfer, without rebate will have to go on. This will affect 25 per cent of all car rides, and will be in operation, if put on, for about one year.

From this it will be seen that the statement that there are 3-cent fares in the four eities mentioned is decidedly misleading. In view of Mr. Jones' insistence on comparing Duluth and Superior it might be expected that he would have compared street railway fares in Milwaukee with fares in St. Paul and Minneapolis, where a straight 5-cent fare is charged. But his only comparison of Milwaukee and the Twin Cities relates to service, and consists of unsupported statements which are not supported by the facts. 
The following facts, for the year 1912, before the improvements in Milwaukee service were ordered, are of interest as showing the fallacy of his conclusions:

\begin{tabular}{|c|c|c|}
\hline & $\begin{array}{l}\text { St. Paul and } \\
\text { Minneapolis }\end{array}$ & Milwaukee \\
\hline Average fare.. & 5.00 cts. & 4.24 cts. \\
\hline Ratio of transfer to revenue passengers. & 37.18 per cent & 36.85 per cent \\
\hline *Net earnings per revenue passenger... & 2.51 cts. & $1.92 \mathrm{cts}$. \\
\hline Revenue passenger per car mile........ & 6.106 & 6.634 \\
\hline $\begin{array}{c}\text { Miles of single track per } 1000 \text { revenue pas- } \\
\text { sengers } \ldots \ldots \ldots \ldots \ldots \ldots \ldots \ldots \ldots\end{array}$ & 0.00187 & 0.00150 \\
\hline Car miles per mile of track. & 87412 & 100675 \\
\hline Car miles per $\$ 1000$ of operating earnings. & 3244 & $\mathbf{3 5 2 4}$ \\
\hline Capitalization per car mile...... & $\$ 1.68$ & $\$ 1.52$ \\
\hline * Net earnings per dollar of capitalizatior & $9.119 \mathrm{cts}$. & 8.412 cts. \\
\hline
\end{tabular}

*Net earnings include amounts available for taxes, depreciation, and interest.

In the light of the facts shown by the foregoing table the claims for superior service in the Twin Cities do not appear to be well supported. It must be remembered, too, that these facts relate to Milwaukee service prior to the service order. With 13,000 more car miles per mile of track than in St. Paul and Minneapolis and with 3524 car miles per $\$ 1000$ of operating earnings as compared with 3244 in the Twin Cities, the service in Milwaukee is certainly not as poor as Mr. Jones would have us believe.

There is perhaps only one other statement made by $\mathrm{Mr}$. Jones which need be mentioned here. He says that "the commission has authorized the issuance of nearly one billion dollars' worth of securities of public utilities." In this statement he leaves the realm of facts entirely. Up to 1911 the commission had no power to prevent the issuance of public utility securities. This power was conferred by the legislature of 1911. Up to June 8, 1914, the commission had authorized the issuance of public utility securities of all classes amounting to $\$ 13,668,435$, of which $\$ 2,684,475$ was for refunding purposes.

A number of utilities are operated in connection with street railways and the securities authorized for these companies are not separable between the utility and the railway businesses. The total authorizations for these companies amounted to $\$ 17,935,000$, of which $\$ 4,585,000$ was for refunding purposes. 
Taking all the issues including the portion for street railways, the authorizations to public utility companies amount to $\$ 31,603,435$, and only $\$ 24,333,960$ of this was for new purposes. This is quite different from one billion dollars, in which Mr. Jones must have included all steam road securities, original and refunding, and then added about 50 per cent for good measure.

The opposition of utility companies to the stock and bond law arises from the fact that the law has prevented over-capitalization, has prevented the manipulation of securities and the unloading of properties on an uninformed public, and has destroyed the field for the wild cat promoter.

There are many other portions of Mr. Jones' paper which might be challenged, but the limits of this article will not permit of a full reply at this time. It is believed, however, that enough has been said to show the fallacy of his argument and the misinformation under which he has apparently labored with regard to the facts. Inasmuch as his attack rests almost entirely upon the "facts" which he quotes and practically not at all upon questions of principle, it seems that no further refutation of his statements need be made. 